\title{
Herbicide residues and perennial grass on establishment perennial pepperweed sites
}

\author{
JAMES A. YOUNG, CHARLIE D. CLEMENTS, AND ROBERT R. BLANK
}

Authors are Range Scientists and Soil Scientist, USDA, Agricultural Research Service, 920 Valley Road, Reno, Nev. 89512.

\begin{abstract}
Perennial pepperweed (Lepidium latifolium L.) is a creeping rooted exotic weed that has infested native hay meadows, riparian areas and agronomic fields throughout the western United States. This highly invasive species causes major losses in forage quality and creates numerous management problems. On many sites infested with perennial pepperweed, a near mono-culture exist. Sustainable suppression programs require the establishment of a competitive perennial species. You can not establish seedlings of a perennial competitive species without some initial substantial reduction in perennial pepperweed stands through weed control. Because tillage is not feasible with this creeping rooted species, herbicidal weed control is the primary option. Experience has shown, that the massive and extensive root system of perennial pepperweed can not be completely eliminated with one application of a herbicide. This means that repeated applications of a selective herbicide are required after the perennial seedlings of a competitive species are established. Perennial pepperweed is a broadleaf species that is some what susceptible to applications of 2,4-D. Therefore, the choice revegetation species is limited to a perennial grass that is resistant to 2,4-D applications at low rates as a seedlings and moderate rates once established. The saline/alkaline nature of the soils where perennial pepperweed is often found limit the adapted perennial grasses to tall wheatgrass (Elytriga elongata [Host] Nevski). The herbicide chlorsulfuron has been shown to be more effective in initially controlling perennial pepperweed than 2,4-D. We determined that applications of chlorsulfuron at rates sufficient to control perennial pepperweed resulted in herbicidal residues that severely reduced or eliminated the establishment of tall wheatgrass seedlings. Application of 2,4-D at flower budding for perennial pepperweed (June), followed by seeding tall wheatgrass in the fall (October), and application of low rates of 2,4-D over the wheatgrass seedlings the next spring (May), gave the best grass seedling establishment and suppression of the perennial weed.
\end{abstract}

Key Words: Chlorsulfuron, tall wheatgrass, saline/alkaline soils

Perennial pepperweed (Lepidium latifolium L.), a native to eastern Europe and Asia (Robbins 1940), was accidentally introduced into North America early in the 20th century (Young et al. 1995). A member of the mustard family, this weed has spread to portions of all western states and adjacent Canada. In the Intermountain Area, perennial pepperweed first became established in riparian and wetland areas. It spread to native hay mead-

Manuscript accepted 16 Aug. 01.

\section{Resumen}

El "Pepperweed" (Lepidium latifolium L.) perenne es una maleza exótica de enraizamiento rastrero que ha infestado las praderas nativas para producción de heno, las áreas ribereñas y los campos de cultivo del oeste de los Estados Unidos. Esta especie altamente invasiva causa perdidas mayores en la calidad del forraje y crea numerosos problemas de manejo. En muchos sitios infestados el " Pepperweed" perenne casi forma un monocultivo. Los programas de supresión sustentable requieren del establecimiento de especies perennes competitivas, pero usted no puede establecer plántulas de especies perennes competitivas sin una reducción substancial inicial de "Pepperweed" perenne mediante el control de la maleza. Debido a que la labranza no es factible con estas especies de enraizamiento rastrero, el control con herbicidas es la principal opción. Las experiencias han mostrado que el sistema radical masivo y extenso del "Pepperweed" perenne puede no ser completamente eliminado con una aplicación de herbicida, esto significa que se requieren aplicaciones repetidas de un herbicida selectivo después de que las plántulas de especies perenes competitivas son establecidas. El " Pepperweed" perenne es una especie de hoja ancha que es algo susceptible a las aplicaciones de 2,4-D. Por lo tanto la elección de las especies para revegetación esta limitada a los zacates perennes que son resistentes a las aplicaciones de 2,4-D en bajas dosis cuando el zacate esta en etapa de plántula y a las aplicaciones moderadas una vez que esta establecido. La naturaleza salina/alcalina de los suelos donde a menudo se encuentra el "Pepperweed" perenne limita la selección al zacate perenne "Tall wheatgrass" (Elytriga elongata [Host] Nevski), adaptado a estas condiciones. EI herbicida clorsulfuron ha mostrado ser mas efectivo en el control inicial del "Pepperweed" perenne que el 2,4-D. Determinamos que aplicaciones de clorsulfuron en dosis suficientes para controlar el "Pepperweed" perenne resultan en residuos del herbicida que reducen severamente o eliminan el establecimiento de plántulas de "Tall wheatgrass". Las aplicaciones de 2,4-D en la etapa de aparición de las yemas florales del "Pepperweed" perenne (Junio), seguida por la siembra de "Tall wheatgrass"en otoño (Octubre) y la aplicación en la próxima primavera (Mayo) de dosis bajas de 2,4-D sobre las plántulas de "Tall wheatgrass" dan el mejor establecimiento de las plántulas de zacate y la supresión de la maleza perenne.

ows and alfalfa (Medicago sativa L.) fields. Native hay meadows located on flood plains are particularly susceptible to perennial pepperweed invasion. The weed is highly adapted, but not restricted to growth on salt affected soils and soils with sodium hazards (Blank and Young 1997). 
Perennial pepperweed plants can produce large quantities of viable seeds (Miller et al. 1986). The plants have extensive creeping root systems. Very small fragments of these roots will produce new plants (Young et al. 1997). This makes mechanical control by tillage virtually impossible.

The invasion of native hay meadows by perennial pepperweed is a threat to the range livestock industry of the Intermountain Area because these meadows are a critical portion of the forage base for both hay production and grazing of crop aftermath. Perennial pepperweed can be partially suppressed by grazing, but if grazing is deferred for hay production the plants become quite woody and the resulting hay is of very poor quality. If herbicidal weed control is practiced on these meadows with near mono-cultures of perennial pepperweed, spontaneous regeneration of the meadow is very slow and reinvasion of the weed will occur. This makes seeding of a perennial forage species necessary. The choice of revegetation for these seasonally dry meadows with salt affected soils is limited. Tall wheatgrass (Elytrigia elongata [Host] Nevski) is the most widely used species.

The standard herbicide for control of perennial pepperweed has traditionally been 2,4-D [(2,4-dichorophenoxy) acetic acid] (Young et al. 1998). More recently, herbicides of the sulfonylurea family, especially chlorsulfuron $\{2$-chloro-N-[(4methoxy-6-methyl-1, 3, 5-triazin, 2-yl) aminocarbony] benzenenesulfonamide have been found to be very effective for the control of perennial pepperweed. Both 2,4-D and chlorsulfuron can be applied at appropriate rates and kill perennial pepperweed in established stands of meadow species and not injure the perennial grasses and grass-like species (Young et al. 1998).

To give the perennial grass plants a chance to biologically suppress perennial pepperweed, repeated herbicide applications are necessary over the seedling stands. This obviously requires the use of a selective herbicide.

The longevity of chlorsulfuron residues and their influence upon tall wheatgrass seedling establishment was unknown for the saline/alkaline soil environments of native hay meadows. Our purpose was to compare seedling establishment of tall wheatgrass on sites where perennial pepperweed was controlled with 2,4-D or chlorsulfuron applications.

\section{Methods}

Field trials were located at the main Station Farm of the Nevada Agricultural Experiment Station at Reno, Nev. (39.30 N. Lat., 119.42 W. Long.). The site was a previously irrigated field which in 1993 became so dominant with perennial pepperweed that crop production was no longer feasible. All weed control and seeding trials in this study were conducted without irrigation. The site is on the flood plain of the Truckee River at the confluence of Steamboat Creek. The topoedaphic position of the site is very similar to typical native hay meadows in the Intermountain Area. The principal soil is the Voltaire series, a fine-loamy, mixed, mesic Fluvaquertic Haplaquoll. Soils are moderately to highly influenced by accumulations of salts. The electro-conductivity of the surface soil ranged from 7.4 to $9.8 \mathrm{~s} \mathrm{~m}^{-1}$ during the summer months. The soil profiles have a well developed natric horizon.

Herbicides were applied with 484 liter $\mathrm{ha}^{-1}$ of water with a boom mounted on an all-terrain vehicle. Initial herbicide applications were made in mid June when perennial pepperweed was in the flower bud stage. The following October, the cultivar Largo of tall wheatgrass was seeded with a rangeland drill at the rate of 7.2 $\mathrm{kg} / \mathrm{ha}$. The initial treatments were, 2,4-D as an amine at $2.2 \mathrm{~kg} / \mathrm{ha}$, chlorsulfuron at $71 \mathrm{~g} / \mathrm{ha}$, and control. The plots 30 by 100 $\mathrm{m}$ in area were arranged in a randomized block design. Initial herbicide application was in June 1996. On separate plots the treatments were repeated in 1996, 1997, and 1998. In April of 1997, one half of

Table 2. Density per $\mathrm{m}^{2}$ of perennial pepperweed plants in October 1997, 1998 and 1999 for treatments made in 1996, 1997, and 1998 and re-treated with $0.6 \mathrm{~kg} / \mathrm{ha}$ of 2,4-D in May 1997, 1998, and $1999 .^{1}$

\begin{tabular}{lcccc}
\hline \hline Treatment & $\begin{array}{c}\text { Year } \\
\text { applied }\end{array}$ & $\begin{array}{c}\text { Year } \\
\text { sampled }\end{array}$ & $\begin{array}{c}\text { 2.4-D } \\
\text { re-applied }\end{array}$ & $\begin{array}{c}\text { Perennial pepperweed density } \\
\text { October }\end{array}$ \\
\hline \multirow{2}{*}{ Control $^{2}$} & & - & - & $\begin{array}{c}\text { (plants/m } \\
\text { 2 }\end{array}$ \\
Control & - & - & 1997 & $24.1 \mathrm{a}$ \\
& 1996 & 1997 & 1998 & $8.4 \mathrm{a}$ \\
& 1997 & 1998 & 1999 & $20.1 \mathrm{a}$ \\
$2,4-\mathrm{D}$ & 1998 & 1999 & 1997 & $0.9 \mathrm{a}$ \\
& 1996 & 1997 & 1998 & $0.3 \mathrm{~b}$ \\
\multirow{3}{*}{ Chlorsulfuron } & 1997 & 1998 & 1999 & $0.4 \mathrm{~b}$ \\
& 1998 & 1999 & 1997 & $0.0 \mathrm{~b}$ \\
& 1996 & 1997 & 1998 & $0.1 \mathrm{~b}$ \\
& 1997 & 1998 & 1999 & $0.1 \mathrm{~b}$ \\
\hline
\end{tabular}

Means followed by the same letter are not significantly different at the 0.01 level of probability as determined by Duncan's Multiple Range Test.

${ }^{2}$ Average of the control plots that were not re-treated with 2,4-D from 1996 through 1998.
Table 1. Density per $\mathbf{m}^{2}$ perennial pepperweed plants in May and October 1997, 1998, and 1999 for treatments made in $1996,1997$. 1998. ${ }^{1}$

\begin{tabular}{|c|c|c|c|c|}
\hline \multirow[t]{2}{*}{ Treatment } & \multirow{2}{*}{$\begin{array}{c}\text { Year } \\
\text { applied }\end{array}$} & \multirow{2}{*}{$\begin{array}{l}\text { Year } \\
\text { sampled }\end{array}$} & \multicolumn{2}{|c|}{$\begin{array}{c}\text { Perennial } \\
\text { pepperweed } \\
\text { density }\end{array}$} \\
\hline & & & May & Oct. \\
\hline \multirow{4}{*}{ Control } & & & \multicolumn{2}{|c|}{-- plants $/ \mathrm{m}^{2}--$} \\
\hline & 1996 & 1997 & $14.1 \mathrm{~b}$ & $24.1 \mathrm{a}$ \\
\hline & 1997 & 1998 & $20.1 \mathrm{a}$ & $23.6 \mathrm{a}$ \\
\hline & 1998 & 1999 & $21.4 \mathrm{a}$ & $24.6 \mathrm{a}$ \\
\hline \multirow[t]{3}{*}{$2,4-\mathrm{D}$} & 1996 & 1997 & $0.1 \mathrm{c}$ & $4.0 \mathrm{c}$ \\
\hline & 1997 & 1998 & $0.1 \mathrm{c}$ & $4.6 c$ \\
\hline & 1998 & 1999 & $0.1 \mathrm{c}$ & $5.2 \mathrm{c}$ \\
\hline \multirow[t]{3}{*}{ Chlorsulfuron } & 1996 & 1997 & $0.1 \mathrm{c}$ & $0.1 \mathrm{c}$ \\
\hline & 1997 & 1998 & $0.1 \mathrm{c}$ & $0.1 \mathrm{c}$ \\
\hline & 1998 & 1999 & $0.1 \mathrm{c}$ & $0.1 \mathrm{c}$ \\
\hline
\end{tabular}

each treatment plot was sprayed with 0.6 $\mathrm{kg} / \mathrm{ac}$ of 2,4-D over top of the tall wheatgrass seedlings. This was also done for the 1997 and 1998 treatments. The treatments that did not have establishment of tall wheatgrass seedlings were re-seeded each subsequent October. For example the plots originally seeded in 1996 were seeded again in 1997 and again in 1998, if no seedlings established.

The plots were evaluated in May and October annually by randomly locating 4 quadrants $1 \mathrm{~m}^{2}$ in each treatment. The density of tall wheatgrass plants per meter of row was determined by randomly locating 10 plots $1 \mathrm{~m}$ in length along the drill rows in each treatment and counting the plants. Data were subject to analysis of variance and means separated by Duncan' Multiple Range Test. 
Table 3. Density of tall wheatgrass plants per meter of row in May 1997, 1998, and 1999 (seedling year) and plant density on same plots in 1998, 1999, and 2000 (second season after planting) with and without re-application of $0.6 \mathrm{~kg} / \mathrm{ha}$ of $2,4-\mathrm{D} .^{1}$

\begin{tabular}{|c|c|c|c|c|c|}
\hline \multirow{4}{*}{\multicolumn{2}{|c|}{$\begin{array}{l}\text { Treatment and } \\
\text { year seeded }\end{array}$}} & \multicolumn{4}{|c|}{ Tall wheatgrass density } \\
\hline & & \multirow{2}{*}{\multicolumn{2}{|c|}{$\begin{array}{l}\text { Without second 2-4-D } \\
\text { Application }\end{array}$}} & \multirow{2}{*}{\multicolumn{2}{|c|}{$\begin{array}{l}\text { With second 2-4-D } \\
\text { Application }\end{array}$}} \\
\hline & & & & & \\
\hline & & Seedlings & $2^{\text {nd }}$ year plants & Seedling & $2^{\text {nd }}$ year plants \\
\hline \multirow{3}{*}{ Control } & 1996 & 0 & 0 & 0 & 0 \\
\hline & 1997 & 0 & 0 & 0 & 0 \\
\hline & 1998 & 0 & 0 & 0 & 0 \\
\hline \multirow[t]{3}{*}{ 2,4-D } & 1996 & $0 \mathrm{~b}$ & $0 \mathrm{~b}$ & $7.1 \mathrm{a}$ & $6.4 \mathrm{a}$ \\
\hline & 1997 & $0.1 \mathrm{~b}$ & $0 \mathrm{~b}$ & $9.1 \mathrm{a}$ & $7.8 \mathrm{a}$ \\
\hline & 1998 & $0.3 b$ & $0 \mathrm{~b}$ & $8.6 \mathrm{a}$ & $7.4 \mathrm{a}$ \\
\hline \multicolumn{6}{|c|}{ Chlorsulfuron } \\
\hline & 1996 & 0 & 0 & 0 & 0 \\
\hline & 1997 & 0 & 0 & 0 & 0 \\
\hline & 1998 & 0 & 0 & 0 & 0 \\
\hline
\end{tabular}

${ }^{\mathrm{T}}$ Whithin treatments means followed by the same letters are not significantly different at the 0.01 level of probability as determined by Duncan's Multiple Range Test. No letters no differences. Seedling and second year plants compared separately.

\section{Results and Discussion}

In May, 11 months after herbicide application, the control of perennial pepperweed plants with either 2,4-D or chlorsulfuron applications appears excellent (Table 1). By October of the year after application, there had been considerable return of perennial pepperweed in the plots treated with 2,4-D.

Application of a light rate of 2,4-D (0.6 $\mathrm{kg} / \mathrm{ha}$ ) over the top of the tall wheatgrass seedlings the spring after they were planted, did not significantly ( $P \geq 0.01$ ) reduce the density of perennial pepperweed in control treatments (Table 2). It did significantly reduce the density of perennial pepperweed in plants in plots that had in the previous year been treated with $2.2 \mathrm{~kg} / \mathrm{ha}$ of 2,4-D. The 2,4-D treatment over the seedlings had no influence on the few perennial pepperweed plants that existed on the plots previously treated with chlorsulfuron.

The establishment of tall wheatgrass seedlings was very straight forward. If you did not control perennial pepperweed no tall wheatgrass seedlings established (Table 3). If you initially controlled perennial pepperweed with applications of 2,4$\mathrm{D}$ a few seedlings of tall wheatgrass were initially present, but no plants were present the second year after seeding. If you initially controlled perennial pepperweed with 2,4-D and followed with a lower rate of 2,4-D over the seedlings the spring after the seeds were planted, very good stands of tall wheatgrass were obtained (Table 3). The plots treated with chlorsulfuron remained virtually free of perennial pepperweed, but no seedling establishment of tall wheatgrass occurred.
The plots treated with chlorsulfuron were re-seeded annually with tall wheatgrass. The plots where chlorsulfuron was applied in 1996, were seeded in 1996 1997, 1998, and 1999. Tall wheatgrass seedlings never established on these areas. Until 1999, the areas initially treated with chlorsulfuron remained weed free except for occasional plants of perennial pepperweed that escaped the initial herbicide application. In 1999 Russian thistle (Salsola targus L.), lamb's quarter (Chenopodium album L.), and annual kochia (Kochia scoparia [L.] Schrader) plants grew on the treated area, but seedlings of tall wheatgrass were not found in the spring 2000 .

These large, replicated experimental treatments were repeated for 3 consecutive years with highly consistent results. Diehard defenders of chlorsulfuron point out that we have done no chemical analysis of the soil to prove that residues of the herbicide are responsible for the failure to establish tall wheatgrass seedlings. The consistency of seedling failure in plots treated with chlorsulfuron while side by side plots treated with 2 applications of 2,4-D have excellent stands of the perennial grass is very compelling evidence for persistent residues. The failure of annual weeds to invade areas treated with chlorsulfuron for 3 years is additional evidence for the existence of residues.

The few perennial pepperweed plants that escape initial applications of chlorsulfuron are a cause of concern. They increased in area by extending creeping roots and putting up additional stems even though perennial grass seedlings could not be established on the plots. The plants are not necessarily resistant to chlorsulfuron.
They may be accidents of faulty herbicidal distribution in the initial application and their depth of rooting allows them to spread below soil horizons with herbicide residues. The existence, persistence, and spread of these plants creates an additional hazard with the use of chlorsulfuron to control perennial pepperweed.

The apparent persistence of chlorsulfuron residues that limit perennial grass establishment is probably heightened by the high $\mathrm{pH}$ of the salt affected soils on the study site. Most native hay meadows where perennial pepperweed is invading have similar soils.

\section{Literature Cited}

Blank, R. R. and J. A. Young. 1997. Lepidium latifolium: Influences on soil properties, rate of spread, and competitive stature. pp. 69-80 In: J. H. Brock, W. Wade, P. Pysek, and D. Green (eds.) Plant Invasion: Studies From North America and Europe. Backhuys Publ., Leiden, The Netherlands.

Miller, G. K., J. A. Young, and R. A. Evans. 1986. Germination of seeds of perennial pepperweed. Weed Sci. 34:252-255.

Robbins, W. W. 1940. Alien plants growing without cultivation in California. Bull. 637. Calif. Agr. Exp. Sta., Berkeley, Calif.

Young, J. A., D. E. Palmquist, and R. R. Blank. 1998. The ecology and control of perennial pepperweed (Lepidium latifolium L.) Weed Techn. 12:402-405.

Young, J. A., D. E. Palmquist, and S. O. Wotring. 1997. The invasive nature of Lepidium latifolium: A review. pp. 59-68 In: J. H. Brock, W. Wade, P. Pysek, and D Green (eds.) Plant Invasion: Studies From North America and Europe. Backhuys Publ., Leiden, The Netherlands.

Young, J. A., C. E. Turner, and L. F. James. 1995. Perennial pepperweed. Rangelands 17:121-123. 